\title{
PENGARUH PSIKOEDUKASI TENTANG MANAJEMEN STRES DALAM MENINGKATKAN SELF EFFICACY KELUARGA MERAWAT ODGJ DI WILAYAH KERJA PUSKESMAS BALOWERTI KOTA KEDIRI
}

\author{
Eka Lutfiatus Solehah ${ }^{1,2}$ \\ ${ }^{1}$ Prodi Ilmu Keperawatan, ${ }^{2}$ STIKes Rana Wijaya \\ Korespondensi penulis: ekasoleha2018@gmail.com
}

\begin{abstract}
Abstrak
Latar belakang: Penanganan gangguan jiwa bersifat multifaktor, artinya setiap penanganan saling terkait dan tidak dapat berjalan masing-masing. Sebagai contoh, seorang pasien yang sudah mendapatkan obat dengan baik, mendapatkan proses perawatan yang baik di rumah sakit, tapi jika tidak mendapatkan dukungan dari keluarga dan lingkungan maka pasien bisa saja kembali relaps.

Tujuan: Tujuan penelitian untuk mengetahui pengaruh pemberian psikoedukasi terhadap self efficacy keluarga merawat pasien ODGJ di Wilayah Kerja Puskesmas Balowerti Kota Kediri

Metode: Desain penelitian yang digunakan yaitu pra experimental dengan rancangan pre post test Design. Variabel penelitian yaitu pemberian psikoedukasi sebagai variabel independen dan self efficacy sebagai variabel dependen. Populasinya adalah seluruh keluarga pasien ODGJ di Wilayah Kerja Puskesmas Balowerti Kota Kediri sebanyak 41 responden. Sampel penelitian diambil dengan teknik total sampling sebanyak 41 responden. Data dikumpulkan dengan lembar kuesioner dan diolah dengan uji wilcoxon.

Hasil: Hasil penelitian menunjukkan bahwa sebelum diberikan psikoedukasi pada keluarga penderita skizofrenia sebagian besar mempunyai self efficacy rendah dalam merawat penderita sebanyak 17 responden (77.3\%) dan setelah diberikan psikoedukasi sebagian besar mempunyai self efficacy tinggi sebanyak 18 responden (81.8\%). Hasil uji Wilcoxon menunjukkan nilai $\rho=0,00<\alpha$ $=0,05$ sehingga $\mathrm{H}_{0}$ ditolak sehingga ada pengaruh pemberian psikoedukasi pada keluarga dalam merawat pasien skizofrenia mempengaruhi self efficacy keluarga menjadi lebih baik dari sebelum diberikan psikoedukasi.

Simpulan: Pemberian psikoedukasi dapat meningkatkan informasi dan wawasan yang dimiliki keluarga sehingga keluarga dapat meningkatkan keyakinan dan kepercayaan diri dalam merawat anggota keluarga yang mengalami gangguan jiwa.
\end{abstract}

Kata kunci: Psikoedukasi, Self Efficacy, Gangguan Jiwa

\section{Pendahuluan}

Kesehatan jiwa masih menjadi permasalahan serius di Indonesia dan masalah tersebut cenderung terus meningkat, sehingga diperlukan tindakan dan penanggulangan yang komprehensif dan berkesinambungan. Falsafah, ciri dan misi Pelayanan keperawatan kesehatan jiwa mengacu pada paradigma keperawatan tentang fenomenal sentral yaitu manusia, lingkungan, kesehatan dan keperawatan untuk dapat memberikan keperawatan kesehatan jiwa yang holistik, komprehensif dan berkesinambungan. Kesehatan jiwa adalah bagian dari kesehatan secara menyeluruh, bukan sekedar terbebas dari gangguan jiwa, tetapi pemenuhan kebutuhan perasaan bahagia, sehat, serta mampu menangani tantangan hidup. Secara medis, kesehatan jiwa diterjemahkan sebagai suatu kondisi yang memungkinkan perkembangan fisik, intelektual, dan emosional yang optimal dari seseorang. Perkembangan tersebut berjalan selaras dengan keadaan orang lain (Febriani, 2008 dalam Putra, 2015). 
Gangguan skizofrenia merupakan gangguan jiwa yang kronis dimana penderitanya sering mengalami relaps atau "kambuh". Penderita memiliki ide-ide yang tidak logis, persepsi yang keliru, aktivitas motorik yang kacau, emosi yang tidak wajar atau tumpul, menarik diri dari relasi interpersonalnya, serta memiliki dunianya sendiri sehingga penderita kehilangan kontak dengan realita dan kehidupannya tidak sesuai dengan tuntutan kehidupan nyata di masyarakat. Tanda-tanda perilaku tersebut seringkali disebut oleh orang awam sebagai ",orang gila" atau orang yang tidak waras". Stigma tersebut yang membuat sebagian besar masyarakat berpikir bahwa penderita „berbahaya"e dan dapat mengancam keselamatan orang-orang di sekitar mereka, sehingga muncul perlakuan-perlakuan diskriminatif kepada mereka, seperti pengucilan, tidak diberikan peran di rumah, diberi kekerasan, dan sebagainya (Wijaya, 2014).

Perlakuan diskriminatif yang diberikan pada penderita juga mempengaruhi proses pemulihan penderita. Proses pemulihan penderita skizofrenia di Indonesia apat dikatakan masih buruk. Proses penanganan tersebut memakan waktu yang lama dan panjang, mulai dari perawatan di rumah sakit, pemberian obat, sampai ke dukungan sosial dari keluarga dan masyarakat (Taufik, 2013). Penanganan ini bersifat multifaktor, artinya setiap penanganan saling terkait dan tidak dapat berjalan masing-masing. Sebagai contoh, seorang pasien yang sudah mendapatkan obat dengan baik, mendapatkan proses perawatan yang baik di rumah sakit, tapi jika tidak mendapatkan dukungan dari keluarga dan lingkungan maka pasien bisa saja kembali relaps. Oleh karena itu, untuk pemulihan kondisi pasien tidak hanya diperlukan obat namun juga diperlukan dukungan dari keluarga atau lingkungan (Wijaya,2014).

Menurut data WHO (2018), terdapat sekitar 35 juta orang terkena depresi, 60 juta orang terkena bipolar, 21 juta terkena skizofrenia, serta 47,5 juta terkena dimensia. Di Indonesia, dengan berbagai faktor biologis, psikologis dan sosial dengan keanekaragaman penduduk; maka jumlah kasus gangguan jiwa terus bertambah yang berdampak pada penambahan beban negara dan penurunan produktivitas manusia untuk jangka panjang. Data Riskesdas 2018 memunjukkan prevalensi ganggunan mental emosional yang ditunjukkan dengan gejalagejala depresi dan kecemasan untuk usia 15 tahun ke atas mencapai sekitar $6.1 \%$ dari jumlah penduduk Indonesia. Sedangkan prevalensi gangguan jiwa berat, seperti skizofrenia mencapai sekitar 400.000 orang atau sebanyak 1,7 per 1.000 penduduk. Berdasarkan data dinas Kesehatan Kota Kediri didapatkan jumlah penderita gangguan jiwa Pada tahun 2018, ada sebanyak 440 orang. Namun tahun 2019 tercatat ada 9.981 orang. Berdasarkan data Wilayah Kerja Puskesmas Balowerti Kota Kediri terdapat sebanyak 41 orang dalam gangguan jiwa (ODGJ) pada bulan Maret-Juni 2020. Hasil studi pendahuluan yang dilakukan di terhadap 5 keluarga dengan pasien ODGJ didapatkan data 4 keluarga merasa terbebani dan merasa malu dalam merawat anggota keluarga yang mengalami gangguan jiwa, sedangkan 1 keluarga menerima keadaan yang mereka alami saat ini dan pasrah dengan apa yang terjadi. Dalam pelaksanaan program edukasi perawatan pasien ODGJ masih belum terdapat keluarga yang menerima edukasi dengan cukup baik tentang perawatan ODGJ.

Keliat (2011) mengidentifikasi factor penyebab kekambuhan adalah pengetahuan, sikap, dan tindakan keluarga dalam merawat pasien gangguan jiwa. Keluarga perlu mempunyai sikap menerima pasien, memberikan respons positif, menghargai pasien sebagai anggota keluarga dan menumbuhkan sikap tanggung jawab kepada pasien, sehingga keseimbangan hidup dalam keluarga dapat terjadi. Adanya gangguan jiwa di keluarga mempengaruhi fungsi keluarga. Keluarga yang berfungsi dengan baik akan dapat memberikan perawatan pada anggota keluarga dengan baik demikian pula sebaliknya. Selain itu kepercayaan diri keluarga (Self Efficay) yang baik akan 
membuat keluarga mampu melakukan perawatan pada paisen ODGJ dengan baik. Self efficacy merupakan prediktor yang kuat untuk merubah maupun untuk mempertahankan perilaku, jika self efficacy baik, maka keluarga memiliki kemampuan merawat baik pula. Kendala-kendala umum yang biasa dihadapi oleh keluarga penderita skizofrenia adalah sulitnya mengakses perawatan mental, biaya pengobatan yang mahal, dan kurangnya penyebarluasan informasi dasar (Taufik, 2013). Biaya perawatan dan pengobatan yang mahal sudah berusaha diupayakan pemerintah dengan pemberian pengobatan secara gratis. Namun, kendala kurangnya informasi dasar mengenai gangguan mental itu sendiri masih belum mendapat perhatian yang serius padahal sebenarnya informasi ini sangat penting untuk membantu keluarga penderita dalam memahami gangguan skizofrenia yang diderita oleh asien. Pemberian informasi dasar tersebut disebut dengan psikoedukasi (Wijaya, 2014).

Tidak dapat dipungkiri keluarga juga akan mengalami krisis dan mengalami tekanan saat mendapati bahwasalah satuanggota keluarganya menderita gangguan jiwa. Tekanan ini akan menjadi sumber stress bagi paraanggota dalam dalam keluarga tersebut. Sementara itu, bagi keluarga yang rentan terhadap stres, tentunya akan mengganggu peran mereka sebagai system support yang berujung pada semakin tidak stabilnya penderita gangguan jiwa dalam proses penyembuhan (Kristyanti\& Rosalina, 2009). Salah satu upaya yang dapat dilakukan untuk mengurangi stress yang dialami keluarga dalam merawat pasien dengan gangguan jiwa antara lain dengan terapi psikoedukasi managemen stress keluarga pasien dengan gangguan jiwa.

Psikoedukasi keluarga merupakan pemberian informasi atau pengetahuan pada keluarga tentang penyakit yang diderita oleh anggota keluarga dengan tujuan untuk mengurangi kecenderungan klien untuk kambuh dan mengurangi pengaruh penyakitnya pada anggota keluarga yang lain (Townsend,2009). Dalam aplikasinya psikoedukasi banyak diberikan pada pasien dengan gangguan psikiatri termasuk anggota keluarga dan orang yang berkepentingan untuk merawat pasien tersebut (Lukens \& Mcfarlane, 2014). Berdasarkan evidance based practice psikoedukasi keluarga adalah terapi yang digunakan untuk memberikan informasi pada keluarga untuk meningkatkan ketrampilan mereka dalam merawat anggota keluarga mereka yang mengalami gangguan jiwa, sehingga diharapkan keluarga akan mempunyai koping yang positif terhadap stress dan beban yang dialaminya. Pendapat lain menjelaskan bahwa psikoedukasi keluarga adalah pemberian pendidikan kepada seseorang yang mendukung treatment dan rehabilitasi (Goldenberg, 2014).

Berdasarkan penjelasan pada latar belakang diatas maka peneliti tertarik untuk melakukan penelitian dengan judul pengaruh psikoedukasi tentang manajemen stress terhadap self efficacy keluarga dalam merawat ODGJ (Skizofrenia) di Wilayah Kerja Puskesmas Balowerti Kota Kediri.

\section{Metode Penelitian}

Jenis Penelitian adalah kuantitatif dengan metode pra eksperiment pretest-posttest design, dimana dalam penelitian ini peneliti akan mengungkapkan perlakuan psikoedukasi diberikan pada keluarga yang merawat pasien ODGJ dengan diawali pretest berupa penilaian self efficay dan setelah pemberian perlakuan pada diadakan pengukuran kembali (pasca-tes).

Populasi penelitian ini yaitu seluruh keluarga pasien ODGJ di Wilayah Kerja Puskesmas Pandaan Pasuruan sebanyak 41 responden yang diambil dengan menggunakan teknik total sampling.

Data dikumpulkan dengan instrument kuesioner tentang self efficacy keluarga pre dan posttest psikoedukasi manajemen stres. Hasil pengumpulan data dianalisis dengan uji Wilcoxon untuk mengetahui perbedaaan self efficaiy pre dan posttest psikoedukasi.

\section{Hasil dan Pembahasan}

Analisis univariat terhadap masingmasing variabel ditampilkan dalam bentuk 
distribusi frekuensi untuk data kategorik yaitu umur, jenis kelamin, pendidikan, pekerjaan, status responden keluarga dan penghasilan keluarga. Sedangkan analisis data univariat untuk penderita yaitu usia penderita, jenis kelamin penderita, status penderita dalam keluarga, lama menderita, pernah MRS atau tidak, kapan MRS terakhir, tempat pelaksanaan kontrol pengobatan dan rutinintas kontrol pengobatan yang dijalani. Hasil analisis univariat yang diperoleh adalah sebagai berikut:

Tabel 1 Distribusi Frekuensi Karakteristik Care Giver di Puskesmas Balowerti Kabupaten Kediri Bulan Oktober $2018(n=41)$

\begin{tabular}{|c|c|c|}
\hline Karakteristik Care Giver & $\mathrm{F}$ & $\%$ \\
\hline \multicolumn{3}{|l|}{ Usia Care Giver } \\
\hline 26-35 Tahun & 2 & 4,9 \\
\hline 36-45 Tahun & 26 & 63,4 \\
\hline 46-55 Tahun & 13 & 31,7 \\
\hline \multicolumn{3}{|l|}{ Jenis Kelamin Care Giver } \\
\hline Laki-laki & 19 & 46,3 \\
\hline Perempuan & 22 & 53,7 \\
\hline \multicolumn{3}{|l|}{ Pendidikan Care Giver } \\
\hline SLTP & 3 & 7,3 \\
\hline SLTA & 30 & 73,5 \\
\hline PT (D3/ S1/S2) & 8 & 19,5 \\
\hline \multicolumn{3}{|l|}{ Pekerjaan } \\
\hline Tidak Bekerja & 2 & 4,9 \\
\hline PNS & 4 & 9,8 \\
\hline Swasta & 20 & 48,8 \\
\hline IRT & 9 & 22 \\
\hline Wiraswasta/Pedagang & 6 & 14,6 \\
\hline \multicolumn{3}{|l|}{ Status Care Giver } \\
\hline Kepala RT/Ayah & 12 & 29,3 \\
\hline Ibu & 12 & 29,3 \\
\hline Saudara/Kakak & 14 & 34,1 \\
\hline Saudara/Adik & 3 & 7,3 \\
\hline \multicolumn{3}{|l|}{ Penghasilan Care Giver } \\
\hline$<$ UMR & 16 & 39 \\
\hline Sesuai UMR & 20 & 48,8 \\
\hline$>$ UMR & 5 & 12,2 \\
\hline \multicolumn{3}{|l|}{ Pengalaman merawat penderita } \\
\hline$<1$ tahun & 8 & 19,5 \\
\hline $1-2$ tahun & 21 & 51,2 \\
\hline$>2$ tahun & 12 & 29,3 \\
\hline
\end{tabular}

Berdasarkan tabel 1 diatas diketahui bahwa karakteristk responden berdasarkan usia sebagian besar berusia 36-45 tahun sebanyak 26 responden $(63,4 \%)$. Karakteristik jenis kelamin care giver sebagian besar adalah perempuan sebanyak 22 responden $(53,7 \%)$, pada karakteristik pendidikan responden diperoleh data sebagian besar merupakan lulusan SLTA sebanyak 30 responden (73,5\%). Karakteristik pekerjaan responden menunjukkan bahwa hampir setengahnya responden bekerja sebagai pegawai swasta sebanyak 20 responden $(48,8 \%)$ dan pada status care giver dalam keluarga hampir setengahnya adalah saudara atau kakak penderita sebanyak 14 responden $(34,1 \%)$. Dan penghasilan care giver hampir setenganya mempunyai penghasilan sesuai UMR sebanyak 20 responden (48,8\%). Berdasarkan pengalaman merawat penderita skizofrenia didapatkan data sebagian besar 
mempunyai pengalaman merawat penderita selama 1-2 tahun sebanyak 21 responden $(51,2 \%)$ dan sebagian kecil merawat $<1$ tahun sebanyak 8 responden (19,5\%).

Hasil penelitian diatas menunjukkan sebagian besar care giver masih termasuk dalam kategori usia produktif meskipun terdapat beberapa yang memasuki usia lansia awal., dan mempunyai latar belakang pendidikan menengah serta mereka juga banyak yang bekerja sebagai pegawai swasta, berdasarkan pengalaman dalam merawat penderita didapakatn sebagian responden sudah mempunyai pengalaman yang cukup lama selama 1-2 tahun sehingga semakin lama responden merawat penderita skizofrenia mak akan semakin mempengaruhi pengetahuan responden dalam melakukan perawatan akan etapi terkadang hal ini dapat menjadi beban secara psikologis keluarga atau caregiver. Karakteristik responden ini menunjukkan bahwasannya responden sudah dapat dikatakan cukup mampu memahami informasi tentang perawatan yang harus dilakukan pada anggota keluarga yang mengalami skizofrenia sehingga keluarga dapat melakukan perawatan dengan tepat, meskipun terkadang ada sedikit kesalahan dalam pelaksanaan prakteknya.

Tabel 2 Distribusi Frekuensi Karakteristik Responden penderita Skizofrenia di Puskesmas Balowerti Kabupaten Kediri Bulan Oktober 2018 ( $\mathrm{n}=41)$

\begin{tabular}{lcc}
\hline \multicolumn{1}{c}{ Karakteristik Penderita Skizofrenia } & F & $\%$ \\
\hline Usia Penderita & 1 & 2,4 \\
\hline $17-25$ Tahun & 31 & 75,6 \\
\hline $26-35$ tahun & 9 & 22 \\
\hline $36-45$ tahun & & \\
\hline Jenis Kelamin Penderita & 21 & 51,2 \\
\hline Laki-laki & 20 & 48,8 \\
\hline Perempuan & & \\
\hline Status Penderita Dalam keluarga & 24 & 58,5 \\
\hline Saudara & 12 & 29,3 \\
\hline Anak & 5 & 12,2 \\
\hline Keponakan & & \\
\hline Lama Menderita & 8 & 19,5 \\
\hline$<1$ tahun & 21 & 51,2 \\
\hline $1-2$ tahun & 12 & 29,3 \\
\hline$>2$ tahun & & \\
\hline Pernah MRS & 18 & 43,9 \\
\hline Ya & 23 & 56,1 \\
\hline Tidak & & \\
\hline MRS terakhir & 23 & 56,1 \\
\hline Tidak & 11 & 26,8 \\
\hline$<1$ tahun lalu & 7 & 17,1 \\
\hline $1-2$ tahun lalu & & \\
\hline Tempat Kontrol & 23 & 56,1 \\
\hline RSU (poli Jiwa & 18 & 43,9 \\
\hline Puskesmas & & \\
\hline Pelaksanaan Pengobatan & 28 & \\
\hline Rutin & 13 & \\
\hline Tidak & & \\
\hline Diagnosa Penderita & \\
\hline
\end{tabular}

Diagnosa Penderita 


\begin{tabular}{lcc}
\hline Waham & 16 & 39 \\
\hline PK & 11 & 26,8 \\
\hline Halusinasi & 9 & 22 \\
\hline Isolasi Sosial & 2 & 4,9 \\
\hline Harga Diri Rendah (HDR) & 3 & 7,3 \\
\hline
\end{tabular}

Berdasarkan table 2 diatas menjelaskan bahwa berdasarkan usia responden sebagian besar berusia 26-35 tahun sebanyak 31 responden $(75,6 \%)$. Berdasarkan jenis kelamin penderita sebagian besar adalah lakilaki sebanyak 21 responden $(51,25)$, berdasarkan status penderita dalam keluarga sebagian besar adalah saudara sebanyak 24 responden $(58,5 \%)$, berdasarkan lama menderita skizofrenia sebagian besar sudah menderita sleama 1-2 tahun sebanyak 21 responden $(51,25)$, berdasakarn pernah MRS atau tidak didapatkan data sebanyak 23 responden $(56,15)$ yang belum pernah MRS, berdasarkan kapan MRS terakhir diperoleh data sebanyak 23 responden tidak pernah MRS dan yang 1 tahun yang lalu sudah pernah MRS sebanyak 11 responden $(26,85)$. Berdasarkan tempat kontrol diperoleh data sebagian besar responden melakukan kontrol di Rumah Sakit Umum pada poli khusus jiwa dan pelaksanaan pengobatan responden sebagian besar melaksanakan pengobatan secara rutin sebanyak 28 responden $(68,3 \%)$. Hasil penelitian ini menunjukkan bahwa sebagian besar penderita skizofrenia masih termasuk dalam usia produktif dan mereka menderita skizofrenia selama 1-2 tahun dan sebagian juga sudah pernah MRS. Berdasarkan diagnose keperawatan terbanyak pada penderita yaitu Waham sebanyak 16 penderia (39\%), kemudian PK sebanyak 11 penderita $(26,8 \%)$ dan disusul dengan halusinasi sebanyak 9 responden (22\%).

Tabel 3 Distribusi Frekuensi Self Efficacy Sebelum dan sesudah pemberian Psikoedukasi pada keluarga penderita Skizofrenia di Puskesmas Balowerti Kabupaten Kediri Bulan Oktober 2018 (n=41)

\begin{tabular}{lcccc}
\hline \multirow{1}{*}{ Self Efficacy } & \multicolumn{2}{c}{ Sebelum } & \multicolumn{2}{c}{ Sesudah } \\
\cline { 2 - 5 } & $\mathrm{F}$ & $\%$ & $\mathrm{~F}$ & $\%$ \\
\hline Rendah & 29 & 70,7 & 9 & 22 \\
\hline Tinggi & 12 & 29,3 & 32 & 78 \\
\hline Total & 41 & 100 & 41 & 100 \\
\hline & $\rho=0,00$ & $\alpha=0,05$ & & \\
\hline
\end{tabular}

Berdasarkan hasil pada tabel 3 menunjukkan bahwa sebelum diberikan psikoedukasi pada keluarga penderita skizofrenia sebagian besar mempunyai self efficacy rendah dalam merawat penderita sebanyak 29 responden $(70,7 \%)$ dan setelah diberikan psikoedukasi sebagian besar mempunyai self efficacy tinggi sebanyak 32 responden (78\%). Hasil penelitian ini menunjukkan bahwa pemberian psikoedukasi pada keluarga dalam merawat pasien skizofrenia mempengaruhi self efficacy keluarga menjadi lebih baik dari sebelum diberikan psikoedukasi.

Hasil uji Wilcoxon didapakan data $\rho=$ 0,00 sehingga $\rho<\alpha=0,05$ maka dapat dinyatakan bahwa psikodukasi tentang manajamen stress dapat meningkatkan self efficacy keluarga dalam merawat pasien skizofrenia di Wilayah Kerja Puskesmas Balowerti Kota Kediri

Berdasarkan hasil pada tabel 3 menunjukkan sebelum diberikan psikoedukasi pada keluarga penderita skizofrenia sebagian besar mempunyai self efficacy rendah dalam merawat penderita sebanyak 29 responden $(70,7 \%)$ dan setelah diberikan psikoedukasi sebagian besar mempunyai self efficacy tinggi sebanyak 32 responden $(78 \%)$. Hasil penelitian ini menunjukkan bahwa pemberian psikoedukasi pada keluarga dalam merawat pasien skizofrenia mempengaruhi self efficacy keluarga menjadi lebih baik dari sebelum diberikan psikoedukasi. 
Skizofrenia adalah gangguan psikotik yang bersifat kronis atau kambuh ditandai dengan terdapatnya perpecahan (schism) antara pikiran, emosi dan perilaku pasien yang terkena. Perpecahan pada pasien digambarkan dengan adanya gejala fundamental (atau primer) spesifik, yaitu gangguan pikiran yang ditandai dengan gangguan asosiasi, khususnya kelonggaran asosiasi. Gejala fundamental lainnya adalah gangguan afektif, autisme, dan ambivalensi. Sedangkan gejala sekundernya adalah waham dan halusinasi (Stuart, 2013). Kecemasan dan stress yang terjadi dalam diri seseorang ketika melakukan tugas sering diartikan suatu kegagalan. Pada umumnya seseorang cenderung akan mengharapkan keberhasilan dalam kondisi yang tidak di warnai oleh ketegangan dan tidak merasakan adanya keluhan atau gangguan somantik lainnya. self efficacy biasanya ditandai oleh rendahnya tingkat stress dan kecemasan sebaliknya self efficacy yang rendah ditandai oleh tingkat stress dan kecemasan yang tinggi pula. Pada keluarga yang merawat anggota keluarganya dengan gangguan jiwa terkadang membuat keluarga meraas tertekan dan stress sehingga dapat mempengaruhi self efficacy mereka.

Psikoedukasi bertujuan untuk membantu orang-orang dengan kondisi kesehatan fisik atau mental tertentu untuk memperoleh informasi yang sesuai dan akurat mengenai kondisi tersebut. Psikoedukasi tidak terbatas pada individu yang menderita penyakit atau gangguan mental saja, melainkan juga dapat diberikan kepada pihak lain seperti keluarga dengan tujuan memberikan informasi yang penting, menjelaskan perilaku yang mendukung penanganan medis (konsumsi obat sesuai dosis, pemeriksaan teratur,) dan memberikan dukungan pada keluarga dengan memberikan harapan bahwa masalah yang dialami oleh salah satu anggotanya dapat ditangani bersama (Anderson, dalam Walsh, 2010).

Hasil penelitian menunjukkan bahwa dengan pemberian psiko edukasi pada keluarga mampu memberikan perubahan keyakinan yang dimiliki oleh keluarga dimana sebelum diberikan psikoedukasi tentang managemen stress banyak keluarga yang mempunyai self efficacy rendah dalam merawata anggota keluarga dengan skizofrenia akan tetapi setelah diberikan psikoedukasi sesuai tahapannya banyak keluarga yang mempunyai self efficacy tinggi. Hal ini ditunjukkan dengan keluarga merasa tenang dalam merawat anggota keluarga yang menderita skizofrenia dan keluarga tidak merasa khawatir dan cemas dalam melakukan perawatan pada penderita skizofrenia tersebut.

\section{Simpulan}

a. Self Efficacy sebelum pemberian Psikoedukasi pada keluarga penderita gangguan jiwa di Wilayah Kerja Puskesmas Balowerti Kota Kediri sebagian besar mempunyai Self Efficacy rendah

b. Self Efficacy sebelum pemberian Psikoedukasi pada keluarga penderita gangguan jiwa di Wilayah Kerja Puskesmas Balowerti Kota Kediri sebagian besar mempunyai Self Efficacy tinggi

c. Terdapat pengaruh psiko edukasi pada self efikasi keluarga dalam merawat pasien dengan skizofrenia di Wilayah Kerja Puskesmas Balowerti Kota Kediri yang ditunjukkan dengan nilai $\rho<0,05$ pada hasil Uji Wilcoxon.

\section{Referensi}

Azizah, Lilik Ma'rifatul. 2011. Keperawatan Jiwa, Aplikasi Praktik Klinik. Yogyakarta: Graha Ilmu

Bandura, A. 2012. Self Efficacy - The Exercise of Control. Fifth Printing. New York: W.H. Freeman \& Company.

Direja, Ade Herman. 2011. Buku Ajar Asuhan Keperawatan Jiwa. Yogyakarta : Nuha Medika.

Donsu, Jenita Doli Tine. 2016. Metodologi Penelitian. Yogyakarta : Pustaka Baru Press 
Ghozali, Imam. 2011. Aplikasi Analisis Multivariate. Badan Penerbit Universitas Diponegoro. Semarang

Harnilawati. 2013. Konsep dan Proses Keperawatan Keluarga. Sulsel: Pustaka As Salam

Kartikasari, 2017. Pengaruh Terapi Psikoedukasi Keluarga Terhadap Self Efficacy Keluarga Dan Sosial Okupasi Klien Schizophrenia. Jurnal Keperawatan Universitas Padjajaran.

Keliat, B. A.2012. Proses Keperawatan Kesehatan Jiwa. Edisi 5. Jakarta: EGC

Nurbani. 2011. Pengaruh psikoedukasi keluarga terhadap masalah psikososial ansietas dan beban keluarga dalam merawat pasien stroke di RSUPN. Cipto Mangunkusumo. Jakarta

Nursalam. 2013. Konsep dan Penerapan Metodologi Penelitian Ilmu Keperawatan. Jakarta : Salemba Medika

Ormrod, Jeanne Ellis. 2010. Psikologi Pendidikan : Membantu Siswa Tumbuh dan Berkembang. Jakarta : Erlangga.

Sugiyono. 2015. Metode Penelitian Kuantitatif, Kualitatif Dan $R \& D$. Cetakan ke-24. Bandung : Alfabeta.

Stuart, G. W., \& Laraia, M. T. 2013. Principles And Practice Of Psychiatric Nursing 10th ed. St. Louis: Mosby Year Book.

Townsend, M. C, 2011, Psychiatric Mental Healt Nursing : Concepts of Care in EvidenceBasedPractice (6th ed.), Philadelphia : F.A. Davis

Wijaya. 2014. Gambaran Psikoedukasi Terhadap Keluarga Penderita Skizofrenia. Psibernetika Vol. 7 No. 2 Oktober 2014 